\section{Supreme Court nullifies patent ruling on living organisms}

\section{David Dickson reports on how a decision about the patentability of computer programs has implications for recombinant DNA technology}

IN a one-line decision that could have important implications for the future development of industrial processes using biological techniques, the US Supreme Court last week ordered an appeals court to reconsider its decision that living organisms can be patented.

Although the exact meaning of the decision is now being hotly debated in Washington, many feel that it is a signal from the Supreme Court that since there is no explicit mention in existing patent legislation that living organisms are covered, the issue of their patentability should be resolved in Congress, rather than by the courts.
In the short term, the court's action means that a number of patent applications for aspects of recombinant DNA techniques, the decisions on which have been held up pending a definitive outcome of the case in question, are likely to remain unresolved for a number of months to come.

The Supreme Court's decision was made on a dispute over a patent which had been applied for by a group of scientists working with the pharmaceutical manufacturer Upjohn Co. for a naturally occurring microorganism, Streptomyces vellosus, which the scientists had isolated, purified and were

\title{
Lederberg suggests national foundation to exploit fruits of university research
}

A National Research and Development Foundation, which would own and exploit the patent rights to inventions made in universities with federal grants money, but at an arm's length from the universities themselves, has been suggested by Professor Joshua Lederberg, president of Rockefeller University in New York. The suggestion has been made in a letter from Professor Lederberg, Nobel Prize-winner and until last month professor of genetics at Stanford University's School of Medicine, in a letter to Senator Gaylord Nelson, whose select committee on small business is currently holding hearings into federal patent policy.

In his letter, Professor Lederberg says that he does not believe the pursuit of proprietary gains to be the proper business of the staff of a university.

"The possibility of profit-especially when other funding is so tight -will be a distorting influence on open communication and on the pursuit of basic scholarship" he said.

Professor Lederberg continues: "On the other hand, the need to protect development investment for the exploitation of inventions is absolutely sound, and essential to the nation's economy. Such investments are typically much larger than the costs of the original research, and are comparable to the expected 'profits'when there is a pay-off.
"It should not be so difficult to reconcile these objectives, using the Research Corporation as a model. Set up an accountable, not-for-profit national $R \& D$ foundation, and vest all government-owned patents in it.

"NRDF will then enter the market, at arm's length, with licences etc. for the inventions it owns. The fees should first of all cover its operating expenses. Then it can use its profits and accumulated reserves to fund grants and contracts that will continue to further the practical applications of scientific discovery."

Professor Lederberg says that universities should not share in the licence fees except to the extent of their cost-sharing in the research that led to the invention, which would be assumed to be 10 per cent for routine cases.

Furthermore individuals should not, in principle, be rewarded for the results of work for which they were already receiving an academic salary, although neither should they be hindered in private arrangements, for the fruits of time and energy for which they were not on salary, and which are outside their normal academic duties.

"The financial and regulatory stresses on our private institutions are threatening their future existence. But patent-seeking is an inappropriate answer to these financial dilemmas," Professor Lederberg says.

David Dickson using to produce the antibiotic lincomycin.

The Patent and Trademark Office had initially turned the patent application down, primarily on the grounds that the patent laws as they now stand contain no indication that they are meant to cover living organisms; in support of this claim, it was argued that if Congress had meant such organisms to be covered, it would not have been necessary to pass a separate Plant Patent Act, as was done in 1930.

Last October, however, in a widely publicised verdict, the US Court of Customs and Patent Appeals reversed the decisions and allowed the patent. The court argued that despite the fact that microorganisms were alive, since they had become an important tool in chemical and pharmaceutical industries, "we do not see any reason to deprive it, or its creator or owner, of the protection and advantages of the patent system".

This ruling was subsequently used as the basis of a further decision by the appeals court in March of this year, which upheld a patent application made by an Indian microbiologist working for General Electric, Dr Ananda M. Chakrabarty, for a Pseudomonas bacterium which had been genetically altered to produce enzymes capable of degrading oil-and hence might provide a useful way of combating oil spills.

If the Supreme Court had upheld he ruling in the Upjohn case-the Justice Department has yet to decide whether to consult it in the second case, although this now seems increasingly likely-it would have set a precedent for granting a wide range of patent applications in the general field of biotechnology, including genetic engineering; and as one patent attorney said in Washington last week "the case would have been closed"

As it is, the court did not take a stand on the issue, but has virtually returned the debate to square one by referring it back to the appeals court, asking that it be re-examined "in the light of" a judgement handed down the previous week in a case over the patentability of computer programs.

In this case, a computer engineer had applied for a patent on a method for updating fire alarms in a chemical engineering process, the only novel aspect of which was the inclusion of a mathematical algorithm (which previous cases had established was not patentable on its own).

The application had initially been rejected by the patents officer on the ground that including an unpatentable step as a novel feature in an otherwise conventional manufacturing process did not make the process patentable. The CCPA disagreed, and reversed the 
decision; but two weeks ago the Supreme Court, in a six to three ruling, overruled the Appeal Court and agreed that a patent could not be awarded.

Patent attorneys are now discussing what the Supreme Court meant when it said that the Upjohn scientist's application should be re-assessed "in the light of" this verdict. One interpretation is that, using a direct analogy, a biological process cannot be patented if its only novel component (namely a living organism) is unpatentable.

However, some feel that the significant point lies in the Supreme Court's statement that its decision did not necessarily imply that computer programs (and by extension microorganisms) are unpatentable, but that existing patent law-which does not consider either-should be read literally. Decisions which imply extending its applicability should be taken by Congress, not the Courts.

How the Court's decision is likely to affect other patent applications, particularly in the field of genetic engineering, is at present uncertain. Of those which have already been filed for recombinant DNA inventions made with the help of federal funds, the most directly related is an application from Dr Roy Curtiss, of the University of Alabama. This application covers not only the techniques for modifying $E$. coli to make it suitable for carrying out high risk experiments, but also includes the modified organism itself.

Less likely to be directly affectedapart from the delay caused while the legal arguments are sorted out-are applications for basic recombinant DNA techniques, such as a joint application pending from Dr Stanley Cohen, of Stanford University, and Dr Herbert Boyer, of the University of California, and two further similar applications from the University of California.

Whether or not the Appeals Court, having reconsidered the case, will stick to its original decision, it seems almost inevitable that the issue will return to the Supreme Court. The logic of last week's decision is that the ball will then be passed on to Congress (which is already preparing itself for such an eventuality, and discussing under whose jurisdiction the issue should fall).

Dr Gilbert Omenn, Assistant Director of the Office of Science and Technology Policy, said this week that the administration would welcome guidance from Congress on how patent applications for living organisms should be handled by the courts.

As far as the industrial uses of genetic engineering are concerned, the outcome may be more of philosophical than economic interest. Most scientists argue that it is the techniques, rather than the microorganisms themselves, for which patent protection would be most valuable (although some feel that plasmids should be patentable).

However, in other areas of the industrial use of biological processessuch as the propagation of complete organisms from a single cell-the issues are more complex. Thus, as the political debate over safety guidelines for recombinant DNA experiments loses its momentum, a related debate on which opinions are just as diverse may soon take its place.

\section{Congress approves solar power satellites- and asteroid mining}

DESPITE opposition from both the administration and environmentalist groups, the US House of Representatives has passed a bill for a major research and development programme that could lead to the design and construction of an array of vast satellites capable of collecting solar power and transmitting it to earth via a microwave link.

The House has agreed by a vote of 267 to 96 to a bill, actively supported by aerospace and utility companies, authorising the expenditure of \$25 million in the fiscal year 1979 for initial research and development on the solar satellite concept. Such a project could eventually involve putting more than a hundred solar collectors in orbit around the earth, and might cost over $\$ 1,000$ billion.

The administration has already proposed a much more modest $\$ 15.6$ million research programme into the feasbility of solar power satellites, spread over a three-year period ending in September 1980. It claims, however, that at present neither the economic necessity nor the technological feasibility of the project has yet been demonstrated sufficiently to warrant the type of public investment that Congress is suggesting.

Environmentalists are also concerned at the environmental hazards associated with the use of microwaves to beam the power from the satellites down to the earth's surface. Many feel hat the aerospace and power industries are merely pursuing their own selfinterest; Representative Richard Ottinger (Dem-N.Y.) for example, the only member of the House Science and Technology committee to oppose the bill, has called the project "one of the greatest boondoggles of all time".

Under the terms of the bill, the Department of Energy and the National Aeronautics and Space Administration would be required to come up with plans for an expanded and accelerated programme for research and development into solar power satellites by next January. The agencies would also be required to study various environmental questions, including the effects of the microwave beams on people and on radio reception.

In a related decision, the Senate last week passed an authorisation bill for the National Science Foundation which included the provision that $\$ 500,000$ of the NSF's funds in 1979 should be spent on examining the feasibility of constructing solar power satellites.

Of particular concern to the administration, however, is the Senate's declaration that the feasibility study should consider orbiting structures "manufactured from lunar and asteroidal materials". This is a concept developed and popularised by Professor Gerald O'Neill of Princeton
University, but which some Congressmen feel pre-empts a whole range of questions about the future of the US civilian space effort.

David Dickson

\section{Carter can kill fast breeder project}

President Carter has won his first victory-albeit slim-in his efforts to get Congress to accept the termination of the liquid metal fast breeder reactor project at Clinch River in Tennessee. This is a project to which he has been consistently opposed, initially on nonproliferation grounds, more recently on technical and economic arguments.

The Senate Energy Committee, although agreeing to include $\$ 159$ million for the project in its Department of Energy authorisation for 1979, has agreed that the project can be terminated if the President feels this to be in the national interest.

However, if Clinch River is terminated, the committee has directed that the money be used for an alternative fast breeder design project for which Congress could later decide whether to proceed to production. Carter has in the past been adamant that he will not commit himself to anything more than a conceptual design study; so a presidential veto remains a possibility. 